CHAPTER 8

\title{
$*$ \\ Reconsidering Literary Criminality in Don Quixote
}

\author{
Ted L. L. Bergman
}

While the picaresque has been studied extensively in Don Quixote, the use of a single literary genre to study a particular aspect of an author's production, namely criminality, can have its limitations. References to criminality are simply deemed 'picaresque', and the picaresque nature is confirmed by citing a picaresque work featuring a similar reference, and again we are led around in a somewhat circular investigation. This circularity can persist, even when sidestepping questions of genre by focusing on biographical information in an effort to obtain a different perspective on criminals and their behaviour in Cervantes's novel. References to criminals or prison life can be linked to the author's own experience, but these are in turn confirmed by adducing yet more of his own literary references, leading us critics around in the same vicious circle. These references are often framed within the picaresque, a tendency reinforced by the fact that Cervantes has written straightforward picaresque fiction elsewhere. This framing is guided by the notion that as much as three of his Novelas ejemplares 'should be considered as full participants in the genre', and driven by the reasonable assumption that Cervantes's strictly picaresque writing must overlap considerably with different sections of his larger novel. While it is sensible and productive to use well-known biographical details and the picaresque genre as a lens through which to study criminal characters, actions, and themes in Don Quixote, there is also much to be gained by widening the scope of Cervantes's experience and by including criminality-themed genres other than the picaresque. A different approach is helpful since the topic of lawbreaking and law enforcement is difficult to avoid in the novel and is broached as early as the prologue to Part One:

¿qué podía engendrar el estéril y mal cultivado ingenio mío, sino la historia de un hijo seco, avellanado, antojadizo y lleno de pensamientos varios y nunca imaginados de otro alguno, bien como quien se engendró en una cárcel, donde toda incomodidad tiene su asiento y donde todo triste ruido hace su habitación? (I. Prólogo, 9).

(And so what could my barren and poorly cultivated wits beget but the history of a child who is dry, withered, capricious, and filled with inconstant thoughts never imagined by anyone else, which is just what one would expect of a person 
begotten in a prison, where every discomfort has its place and every mournful sound makes its home? $)^{2}$

The author's imprisonment in the Cárcel Real de Sevilla must have informed his thoughts on crime and punishment, but it is important to resist the temptation solely to fall back on literary examples when seeking to explore the topic further. An example of this limiting point of view is found in a passage from José Miguel Cabañas Agrela's Breve historia de Cervantes in which he seeks to paint a vivid picture of the criminal element that surrounded the author inside and outside of jail:

[Sevilla] era la meca de la picaresca por antonomasia, como lo demuestran las novelas de este género de la época. Existía en España una ruta de la picaresca que recorría el reino de norte a sur, desde Burgos hasta Sevilla, pasando por Madrid, Toledo y Córdoba, por donde, como peregrinos de la delincuencia, se dirigían todos los desheredados y maleantes a Sevilla, su santuario ideal. Y es que aquí, como en el crimen organizado, incluso se reunían en cofradías de rufianes, con una estricta organización jerárquica y un respeto escrupuloso a sus leyes, por parte de quienes, paradójicamente, no respetaba las oficiales. Nadie ha descrito mejor este submundo sevillano y estas organizaciones del delito como Cervantes en su famosa novela Rinconete y Cortadillo cuando nos muestra el patio de Monipodio y su mundo, que él mismo controla y mantiene alrededor suyo como un padre que se ocupa de su numerosa familia para que no les falte un mendrugo de pan que llevarse a la boca, pero también bajo unas estrictas reglas que cumplir. Pícaros, ladrones y rufianes de toda laya convivían, por tanto, asociados, con una organización, una jerarquía y uno o varios jefes - como el Monipodio cervantino, personaje real y al que con toda seguridad Cervantes conoció. ${ }^{3}$

(Seville was the picaresque mecca par excellence, as shown by the novels of the era belonging to this genre. In Spain there was a picaresque route that wound its way through the kingdom from north to south, from Burgos to Seville, passing through Madrid, Toledo and Cordoba. Along this road, like a group of pilgrim delinquents, all those who were villainous and disenfranchised made their way to Seville, their ideal sanctuary. And it is here, as in organized crime, that we find brotherhoods of thugs, with a strict hierarchical organization and a careful respect for for its laws on the part of those who paradoxically did not respect official law. Nobody has described this Sevillian underworld and these criminal organizations better than Cervantes in his famous Rinconete and Cortadillo when he shows us Monipodio's courtyard and his world. The character controls and maintains order in his surroundings like a father looking after a large family to ensure that they have a crust of bread to eat, but it is also a world with strict rules that must be followed. Rogues, thieves, and pimps of every stripe lived to together, and in this way are associated with an organization, a hierarchy and one or several bosses - like Cervantes's Monipodio, a real person and whom Cervantes surely met.) ${ }^{4}$

The words 'picaresca' or 'pícaro' are used three times above, and in the paragraph previous to the one in the quotation, Cabañas Agrela cites the picaresque novels $\mathrm{La}$ vida del escudero Marcos de Obregón and Guzmán de Alfarache as sources on Seville's underworld, while conceding that Mateo de Alemán may have used poetic licence when describing the abundant wealth of the city. The historian Cabañas 
Agrela's reliance on fictional accounts is not unusual, although he seems overly dependent when he writes: 'Nadie ha descrito mejor este submundo sevillano y estas organizaciones del delito como Cervantes en su famosa novela Rinconete $y$ Cortadillo' (Nobody has described this underworld of Seville better than Cervantes in his famous novela Rinconete and Cortadillo). Mary Elizabeth Perry, who literally wrote the book on Crime and Society in Early Modern Seville, is more circumspect:

Monipodio's organization is fictional, and Cervantes' motives in writing this story must be examined. Undoubtedly he wanted to delight his public as well as to describe in loving irony a society that he had known on the streets and in the Royal Prison of Seville. The many details he included and the evidence of criminal organization he amassed suggests that he was consciously trying to make a point about it. His story satirized a society in which each person had his role and his territory secure so long as he did not question the people above him who took a share of his earnings. ${ }^{5}$

In order to see what the city was really like, it is useful to read first-hand accounts when dealing with very specific locations such as the Cárcel Real de Sevilla. The historian and criminality-in-Seville scholar Herrera Puga would agree:

al considerar el ambiente de la Cárcel en todas su dimensiones picarescas, se llega al convencimiento de ser éste uno de sus aspectos más importantes y, al mismo tiempo, el foco principal de donde irradia gran parte de la fuerza secreta de nuestra literatura. ${ }^{6}$

(when considering the atmosphere of the Jail in all its picaresque dimensions, one arrives at the conclusion that this is one of its most important aspects, and at the same time, the main focal point from which a great deal of the secret power of our literature emanates.)

This ambiente must not be not accessed through Cervantes himself, nor other writers of the picaresque, but can be read through modern historians and their primary sources. Returning to Cervantes's prologue, a single word can take on new significance if we momentarily turn away from picturesque satire as the reference point for our criticism. Simultaneously, it is important to remain focused on the criminal ambiente, a context wider than the immediate biographical circumstances of the author. In their notes about Cervantes's prologue cited above, Ellen M. Anderson and Gonzalo Pontón Gijón write:

La frase no aclara de suyo si tiene un sentido literal o metafórico, pero el cervantismo ha optado mayoritariamente por creer que la expresión debe tomarse al pie de la letra: el Quijote se ideó, e incluso empezó a escribirse, mientras Cervantes permanecía recluido en una prisión. ${ }^{7}$

(This phrase in itself does not make clear if it is meant literally or metaphorically, but the majority of Cervantes scholars have opted for the view that the expression should be taken at face value: Don Quixote was conceived, and also began to be written, while Cervantes was locked up in a prison.)

The two critics then briefly examine a debate about how much of the novel was actually written in prison. They conclude that it is best to 'suponer únicamente que el primer aliento de la historia, la percepción de su contenido, le sobrevino 
a Cervantes mientras permanecía en prisión' (suppose only that the inspiration for the story, the idea for its content, came to Cervantes while he was in prison). ${ }^{8}$ The focus here moves to the novel's date of composition, and attendant debate about reality-versus-metaphor has ignored the concrete sense of such words as incomodidad (discomfort) whose mundane appearance masks a deeper understanding of the ambiente in question. Historical accounts reveal that the Cárcel de Sevilla was more than a place of misery. It was also a business operation in which incomodidad was a driver of profit. Not only the wardens, but the prisoners themselves preyed financially on the incarcerated population through any number of scams and small entrepreneurial ventures. Drawing on Cristóbal de Chaves's Relación de las cosas de la cárcel de Sevilla y su trato as a source, Perry writes: 'The assistant warden had up to 400 special cells that he could rent for fourteen or fifteen reales a month', and,

some enterprising prisoners stood guard at an entrance to the prison latrine and charged prisoners a small amount to use the stepping stones they had placed there to pass through the filth. Others charged a fee for providing a support that helped make more bearable the punishment of suspension by wrist shackles high above the ground. ${ }^{?}$

Within this quotation we can find inspiration for Cervantes's thoughts on crime, punishment, and corruption. Don Quixote features a complex web of interconnected points of reference, seeds of ideas that later bear fruit; and the author's stay in the Cárcel Real de Sevilla can be used to illuminate other areas of the novel in which criminality is manifest. The galeotes (galley slaves) episode (I. 22) is a good example of this. The common course for investigation is to follow up allusions to Guzmán de Alfarache and explicit references to Lazarillo de Tormes, meaning to start and likely end with the picaresque as a point of reference. In his notes to a chapter on Ginés de Pasamonte, Gerald R. Gingras points out that not every critic follows this path unreflectively. ${ }^{\text {IO }} \mathrm{He}$ cites Peter N. Dunn, who insists that Cervantes was not inserting fragments of a coherent and consensus-driven picaresque genre into his novel. Dunn's approach contrasts with that of E. C. Riley, who seven years later would reinforce the more common interpretation that 'Cervantes has contrived powerfully to suggest a confrontation between two kinds of prose fiction: the picaresque and [...] the new novel of Cervantes.' ${ }^{\text {I }}$ Among modern critics, the picaresque as a foundation for analysing criminality in Don Quixote is difficult to avoid. For example, Juergen Hahn's study mixes in the topics of giants and savagery but has the picaresque at its core. He writes:

[Don Quixote] does after all live out his imagination beyond the pale of normal society, the more or less orderly, acceptable bourgeois existence, just like the picaro. And even though his value system is miles apart, his disruptive effect on 'normal' societal values is often similar. For while the picaro indulges his frequently petty, and sometimes grandiose criminality, Don Quijote, in spite of his lofty intentions, too manages to place himself in a criminal position vis-a-vis normal society. This is especially evident in his encounter with the galeotes. ${ }^{\text {I2 }}$

There are many different ways to shift the focus from the picaresque when looking 
at criminality in Don Quixote, but the pull of the genre remains strong. When explaining the significance of an omniscient narrator in El licenciado Vidriera, Michael Gerli contrasts it with the 'the first-person narrations of picaresque novels in the Galeotes episode of Don Quijote (I. 22)'. ${ }^{\mathrm{I} 3}$ At the same time, studying another narrator, neither omniscient, nor first-person, can lead us to another point of view that breaks us free from the picaresque paradigm. While Ginés de Pasamonte is a captivating figure and can influence our own judgements as critics, we should also heed the words of his guardian, the comisario, who tells us that "él [Ginés] mesmo ha escrito su historia, que no hay más que desear, y deja empeñado el libro en la cárcel en docientos reales' (I. 22, 265) ('He wrote his own history himself, as fine as you please, and he pawned the book for two hundred reales and left it in prison'). ${ }^{\text {I4 }}$ When studying criminality in this context, the natural next step would be to head mentally towards the galeotes's destination, the galeras (galleys), leading to inevitable comparisons with Guzmán de Alfarache. But why not take a different route, or indeed reverse direction entirely? Why not focus more on the comisario's words and look backwards to the cárcel itself, quite possibly the same Cárcel Real de Sevilla where Cervantes himself stayed? That Ginés has pawned his book at the prison may seem purely picturesque and picaresque, but only if we disregard Cristóbal de Chaves's account of the financial give-and-take that was an integral part of the prison system and no doubt integral to Cervantes's day-to-day incomodidad. Likewise for other prisoners, the evidence of the justice system's corrupt nature does not need support from picaresque fiction and such a focus may even obscure real-world connections between the fictional and factual prisoners. One galeote explains that 'si a su tiempo tuviera yo esos veinte ducados que vuestra merced ahora me ofrece, hubiera untado con ellos la péndola del escribano y avivado el ingenio del procurador' (I. 22, 26I) ('if I'd had those twenty ducados your grace is offering me now at the right time, I'd have greased the quill of the clerk and sharpened the wits of my attorney'). ${ }^{\text {Is }}$ In Don Diego Clemencín's notes to the 1833 edition for this passage, he explains that 'nuestros libros de entonces hablan de la corrupción y venalidad de los escribanos como de cosa ordinaria' (our books from back then speak of the corruption and venality of the scribes as something ordinary). ${ }^{\mathrm{I}}{ }^{\mathrm{C}}$ Clemencín calls one of the galeotes's reference to 'perder los tragaderos' ('having one's gullet in a noose') ${ }^{17}$ a 'metáfora picaresca' that must also be treated as a 'testimonio' among many. ${ }^{\mathrm{I}}{ }^{8}$ According to the nineteenth-century critic, similar 'testimonios' by 'infinitos escritores coetáneos' (countless contemporary writers) can be found in such works as the Corbacho, Celestina, Propaladia, Lazarillo de Tormes, Guzmán de Alfarache, La pícara Justina, El coloquio de los perros, Rinconete y Cortadillo, 'el Tacaño de Quevedo, y el Teatro de Lope y de Calderón': in short, all fictional sources. ${ }^{19}$ Such a judgement from nearly two hundred years ago may seem antiquated, but still today it is difficult to shake off the influence of literary tradition and take account of the real-world context that informs a genre. This is particularly true if one takes genre itself as a starting point. In his Crítica de los géneros literarios en el 'Quijote', Jesús G. Maestro writes first that 'el encuentro con los galeotes cita a don Quijote directamente con el mundo de la picaresca' (the encounter with the galley slaves places Don Quixote directly in the 
world of the picaresque). ${ }^{20}$ The foundation of this 'mundo' is Lazarillo de Tormes, and built upon it are 'Guzmán de Alfarache, Vida del escudero Marcos de Obregón, Vida del Buscón, La pícara Justina, La hija de Celestina, Vida y hechos de Estebanillo González [...]'. ${ }^{2 \mathrm{I}}$ Returning to the passage from the galeotes episode about bribing the escribano and procurador, a new perspective requires a source that stands apart from the picturesque satire of the picaresque. Padre de León, a sort of early-modern 'prison worker', wrote about the lack of money among prisoners at the Cárcel Real in graphic and sincere terms, with sympathy instead of the acerbic wit that is integral to the picaresque:

Habiendo, pues, considerado con mucha atención el grande número de presos indefensos y olvidados por no haber quien diese un paso por ellos sin interés, sino a poder de dineros, haciéndoles increyentes los escribanos y procuradores que con tantos reales que les diesen (como tengo dicho), y aunque yo y otros veinte de la Compañía de Jesús anduviéramos en la solicitud de estos presos olvidados, no hiciéramos la centésima parte de lo que era menester. ${ }^{22}$

(I thus considered with great attention the large number of defenceless and forgotten prisoners for whom nobody would intervene unless for some gain, through the power of money, and how scribes and prosecutors had ruined the faith of the prisoners by all the reales that they demanded of them, as I have mentioned. Even if I and twenty more from the Company of Jesus were to advocate for these forgotten prisoners, we would not manage to do one hundredth of what was necessary.)

This example casts the fictional galeote's words in a much less cheeky, less picaresque light, and directly connects the fictional character's circumstances with Cervantes's own incomodidad mentioned in the prologue. The destitute galeote, and the officials who wanted money and were of no help to the prisoner, do not have to be treated as objects lifted from an assembly line of picaresque novels and made into the butt of a simple joke. Instead, these characters can be considered reflections of unfiltered real-life experience suffered by Cervantes's fellow inmates. It is difficult to argue against the heavy influence that Lazarillo and Guzmán de Alfarache, or even their successors, must have had on the galeotes episode. Nevertheless, one cannot deny the usefulness of casting a wider net for catching sources that have always been available but neglected due to a one-sided generic approach. Historical sources are only one resource, while another is found in criminality-themed genres that are distinct from the picaresque prose of Lazarillo, Guzmán, and company.

The specificity of language in the galeotes episode opens a pathway to a more varied exploration of genre influences. Both fictional galeotes and Cervantes survived incarceration with their wit(s) intact, and a sense of humour is useful in dealing with the incomodidad of going to jail. The jokes told by the prisoners in Chapter 22 take the form of what Clemencín called 'metáfora picaresca', but more accurately should be described as a playful use of germanía, witty and stylized underworld jargon. Once again, the tendency to use the picaresque as a lens through which to view the episode is difficult to avoid. Over a century after Clemencín's comments, when listing the puns used by the galeotes, Joaquín Casalduero wrote: 
Cervantes se sitúa en este juego verbal: 'por enamorado', 'por cantor', 'por faltarme diez ducados', 'por haber sido corredor de oreja', 'porque me burlé', y este juego verbal es la sordina irónica que se pone a la visión picaresca de la vida. $^{23}$

(Cervantes positions himself amidst this wordplay: 'for being a lover', 'for being a singer', 'for not having ten gold ducados', 'for trading in ears', 'because I made too merry' and this wordplay is the ironic damper placed upon the picaresque view of life. $)^{24}$

Sixty years after that, Anthony Close also refers to the picaresque, but only after listing a number of other influences: 'The Quixotic adventures of Part I, including [the galeotes episode], are saturated with echoes of robustly comic species of previous literature and folklore: farcical interludes and other motifs of theatre, fabliaux and novellas, popular jests, the picaresque novel. ${ }^{25}$ For Close, farce plays a big role in the form of Lope de Rueda's pasos, and the critic cites a very good example from the fourth paso of the Registro de representantes. The sketch features a conversation of 'comic casuistry' that ends with the punch line, 'Pues ¿qué afrenta recibo yo que me azoten, si es contra mi voluntad y por fuerza?' (And another thing: one can't call it an affront if what a man suffers is inflicted on him by force, not freely consented to). ${ }^{26}$ Close also cites jokes based on 'euphemistic allusions to shameful punishments to be inflicted on his nearest and dearest, like being pilloried, whipped, tortured', and implies that such jokes mostly stem from a folklore tradition. ${ }^{27}$ As he writes elsewhere, 'The relation of DQ to folklore and popular traditions has been the speciality of traditional Spanish philology and French Hispanism' and includes 'important considerations on C[ervantes]'s portrayal of character and its roots in popular jests in Maxime Chevalier' and 'Monique Joly's innovative La bourle et son interprétation analyses the terminology and practices of popular jokes, taunts, hoaxes and their assimilation in picaresque literature'. ${ }^{28}$ Studying both Lope de Rueda and Cervantes within the cuentecillo (short story) tradition is a productive enterprise, but following the lead of Chevalier or Joly when examining bitterly ironic jokes about crime and punishment is only one path among many that we can take in deepening our understanding. While it makes sense to start with folklore and move towards the picturesque as an endpoint, such a direction draws our attention away from another genre that can shed light on the galeotes episode. That genre is the jácara, of which a key characteristic is germanía-based wordplay that communicates the harshest violence in an understated comical tone. The criminal jargon so common to the jácara is part of a popular tradition, but not one born in the countryside or marketplace. Instead, germanía reflects the folklore of urban prisons like the Cárcel Real de Sevilla, a context quite different from that found in a typical cuentecillo:

los germanos utilizaban permanentemente la lengua popular, en alguna de sus variedades más bajas, y las estructuras generales del registro coloquial. Y en él insertaban sus peculiaridades léxicas e introducían algunas rupturas propias; es decir, que no utilizaban germanía de manera permanente al comunicarse, si bien procuraban insertar sus variedades con la mayor frecuencia posible. Por otra parte, estas creaciones no se programaban: eran fruto de la agudeza de ingenio de algún germano, que por la oportunidad de la creación, por el 
prestigio de su creador entre la germanesca o por convenio de un pequeño grupo, se difundía, generalizaba y estabilizaba. ${ }^{29}$

(underworld figures always used popular language, in some of its basest varieties, along with the general structures of a colloquial register. Into this they injected lexical peculiarities and introduced their own breaks from the norm. In other words, they did not use underworld jargon as a fixed mode of communication, since they attempted to add variations as frequently as possible. What is more, these creations were not programmatic: they were the fruits of the sharp wit of some criminal, that through the opportunity for creation, through the prestige of their creator in the underworld, or by the agreement of a small group, were disseminated, generalized, and stylized.)

Because 'agudeza de ingenio' was integral to germanía, its appeal was immediate to Francisco de Quevedo, who wrote jácaras that, according to José Manuel Blecua, were greatly admired by Cervantes. ${ }^{30}$ Blecua cites a romance from La ilustre fregona as an example of this admiration and imitation, while the example cited by most critics is the Entremés del rufián viudo llamado Trampagos. The sketch ends with an appearance by the jaque (thug) Escarramán whose signature dance is accompanied by musicians who play his theme song, one lifted from one of Quevedo's own jácaras. ${ }^{3 \mathrm{I}}$ Aside from the broader theme of criminality, there is a specific lexical connection between Don Quixote's galeotes scene, Cervantes's entremés, and the jácara genre as a whole. The connection is through the word 'gurapas'. In the entremés, the musicians sing:

\author{
Ya salió de las gurapas \\ El valiente Escarramán \\ Para asombro de la gura, \\ Y para bien de su mal. ${ }^{32}$ \\ (That tough guy Escarramán, \\ Once in the galleys, just got out. \\ It's quite a shocker for the cops, \\ But good for curing what ails him.)
}

'Gurapas' is a term that separates Don Quixote's understanding of the world from that of the galeotes whom he feels compelled to liberate: ' - ¿Qué son gurapas? preguntó don Quijote. - Gurapas son galeras — respondió el galeote' (I. 22, 259) ('What are gurapas?' asked Don Quixote 'Gurapas are galleys,' responded the galley slave). ${ }^{33}$

The word also signals a lack of generic awareness in the hero because it is tightly bound to the 'euphemistic allusions to shameful punishments' (to repeat Anthony Close's observation) so often used in the jácara genre. It is this lack of awareness that presents the main obstacle to communication between Don Quixote and the prisoners. The following lines from different jácaras in Juan Hidalgo's I609 collection Romances de germanía demonstrate the irony, violence, and humour surrounding 'gurapas' in a literary context:

\footnotetext{
Al fin el Guro ha mandado, que en pago de lo servido, le corten entrambas Mirlas [orejas]
} 
por el lugar mas crecido.

Y esté recluso diez años

en las Gurapas metido,

en orden de Tercerol [galeote de tercer banco],

escribano sin partido [...].

[...]

El reside en las Gurapas

Cumpliendo lo prometido:

Un argolla y su palabra

son fiadores del partido [...]. ${ }^{34}$

(In the end the cops demand

Payment for his services:

Both ears must be cut off

From that magnificent head.

And he's secluded for ten years,

Cloistered in the galleys,

A scribe without a district to attend $[\ldots]$

$[\ldots]$

He resides in the galleys,

Completing his end of the deal:

A shackle and his word

Will vouch for his agreement.)

In another jácara, we hear the equally cynical voice of a jaque's marca (moll):

Solo a ti por quien he hecho

en la Trena y en la Altana,

y en las Gurapas metido

sin mancar de tu demanda.

$\mathrm{Y}$ en los destierros y clamos

de ti sin faltar hallada,

agora es tiempo alma mía,

que sea remunerada. ${ }^{35}$

(Only for you, for whom

I've done so much while

You were stuck in either

Prison, Sanctuary, or Galleys.

Through banishments and bounties,

ever at your service,

Now it is time my love,

That I get what is my due.)

The jaque Maladros suffers a similar punishment as the figure in the first jácara cited above:

Vino desde allí a Sevilla

do le fue otro cotón dado:

y cortadas ambas mirlas

$\mathrm{y}$ a las ansias entregado.

Donde sirvió de Proel 
a la Corulla amarrado, cumplida su penitencia y pasados ya seis años [...] Y dejando las Gurapas a Sevilla volvió el calco, y por sustentar el Rozo altanóse en allegando. ${ }^{36}$

(He came from there to Seville, Where he was given more lashes: And had both ears cut off, And was stretched on the rack. He served as a sailor at the prow, Tied to the bridle of the oars, And did his penance, After six years gone by. [...] And leaving the galleys, He headed for Seville, And to earn his bread He made himself a pimp.)

When Maladros from the jácara above is tortured on the rack, he 'sings' in a manner that is full of wordplay but generically far removed from the bulk of 'the firstperson narrations of picaresque novels, ${ }^{37}$ whose scenes of torture or mutilation are exceedingly rare compared to the constant presence of these in the jácara genre.

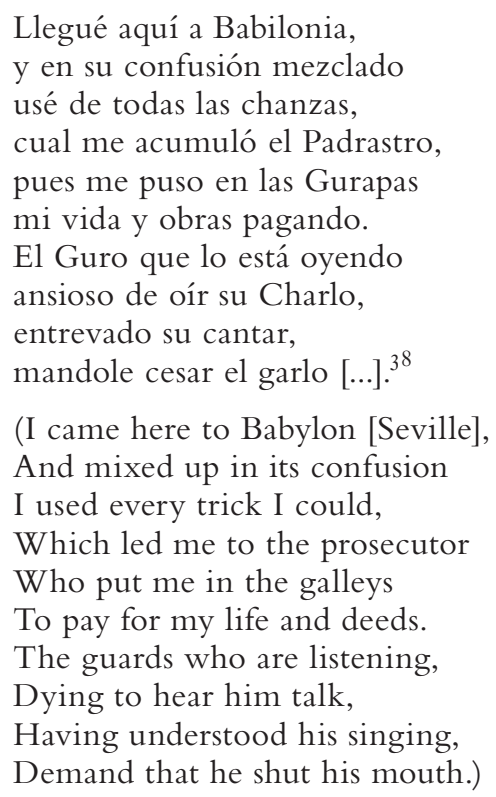

'Cantar' is the common jácara reference to torture spoken by the galeote who says to Don Quixote, 'no hay peor cosa que cantar en el ansia' (I. 22, 260) ('there's 
nothing worse than singing when you're in difficulty'). ${ }^{39}$ To call a joke such as this a 'metáfora picaresca', as Clemencín does, for 'perder los tragaderos', is to undercut the painfulness of a situation that no amount of irony can mask. Having one's body twisted on the rack or, as in the jácaras above, having one's ears sliced off, is far more cruel than the beatings suffered by Lazarillo, Guzmán, Pablos, Estebanillo, and their ilk. To this torture we must add the hundred lashes, mentioned by one of those guarding the galeotes. This takes us quite far from the standard playful tone of the picaresque, barring extreme exceptions. If Guzmán de Alfarache did inspire Cervantes, then what are we to make of the following observation: 'Closing [Guzmán's] novel with the description of his own torture for a crime he did not commit changes the entire tenor of the novel'? ${ }^{40}$ The non-picaresque level of harshness of punishment can be debated by way of discussions about Cervantes's ambivalence towards the picaresque or handling of the genre, ${ }^{4 \mathrm{I}}$ but the analysis can be taken in another direction by ignoring specific references to the picaresque altogether and instead focusing on the jácara. For Emma Nishida, the use of germanía and indebtedness to a jácara tradition lead her to Quevedo's Escarramán in a search for 'mensajes pícaros de Cervantes hacia Alonso Fernández de Avellaneda' (cheekypicaresque messages sent by Cervantes to Alonso Fernández de Avellaneda). ${ }^{42}$ Such is the draw of the picaresque, but why not continue to move in another direction and thus grant a larger role to the jácara in the novel? To borrow Felipe Pedraza Jiménez's term, why not describe the galeotes episode as a 'jácara en prosa de Cervantes'? Pedraza Jiménez uses the idea to study an example from Los trabajos de Persiles y Sigismunda and not so much Chapter 22 of Don Quixote. Despite this shift away from criminality-themed genres, the critic helpfully reminds us that Francisco Rodríguez Marín drew attention to the jácara as a literary inspiration for Cervantes back in $1947 .^{43}$ Since the days of Rodríguez Marín, few critics have taken a look at the role of romances de germanía in Cervantes's supremely inter-generic novel, and those who do rarely look beyond Quevedo. This is likely due to an overall neglect of the jácara genre in comparison to the attention lavished upon the picaresque. An imbalance of scholarly interest is justified, as the picaresque undoubtedly had more impact than the jácara on prose authors, but the current degree of critical attention deficit requires some amount of remedy.

Returning to the relationship between language, literature, and prison life in Don Quixote, there remain some autobiographical connections that, like the generic ones examined above, deserve more attention. Cervantes's understanding of different cultures is attributed to his travels, especially when he is forced into close contact with them, as in the case of his imprisonment in Algiers. On the other hand, since many of Cervantes's brethren in the baños were not strictly imprisoned for breaking the law per se, the relationship between explicit criminality and diverse cultural perspectives is better studied in the context of Cervantes's other incarceration, namely in the Cárcel Real de Sevilla. Mary Elizabeth Perry writes that the prison was 'a cultural meeting place', explaining further that,

as a meeting place for prisoners and outside groups, the prison emphasized the subordination of prisoners to the larger society and their dependence on outside 
support, but it also provided a meeting place for the variety of people who came together as prisoners. They were from Portugal, Italy, and most parts of Spain. They were between fourteen and eighty years of age. Many were penniless, a few were wealthy - although the wealthy prisoners often kept to their own better quarters. Some, such as Lope Ponce, came from well-known noble families. In no other place in Spain could so many varieties of people meet together to enrich and reinforce an underworld culture. ${ }^{44}$

This context may help us better understand the concentration of italianismos (Italianisms) in the second part of Don Quixote within the span of Chapters 24-25. These are comprised mostly of the 'aventura del rebuzno' (II. 25, 9I2) ('braying adventure' $)^{45}$ and Maese Pedro episodes, the second of which features the disguised master criminal facing the novel's hero. Carlos Romero Muñoz lists italianismos uttered by three characters: the man with the lances on his way to the inn ("hacer placer', 'no que', 'contraseño') (II. 25, 9I3, 9I4, 9I5) ('to have one appreciate', 'let alone', 'signal'), ${ }^{46}$ the innkeeper ('es hombre galante, como dicen en Italia, $y$ bon compaño') (II. 25, 918), ('gallant man and a good companion, as they say in Italy' ${ }^{47}$ and Don Quixote himself ('espilorchería', ‘qué peje pillamo?') (II. 24, 9IO and II. 25, 9I8) ('miserliness or stinginess', 'what are we up to?). ${ }^{48}$ Maese Pedro stands apart from the other three because he does not employ such phrases. ${ }^{49}$ Why does he refuse? Perhaps he resists contributing Italian affectations to the conversation because he is wary of being identified, even tangentially, with the criminal underworld. The italianismos are affectations because they are functionally unnecessary, unlike the use of Italian as a lingua franca when a German pilgrim takes Sancho's hand in Part Two, Chapter 54, and says, 'Español y tudesqui, tuto uno: bon compaño' ('Spaniard and German, together: good friends'), to which Sancho responds: ‘Bon compaño, jura Di!' (II. 54, II69) ('Good friends, by God!')..$^{\circ}$ Romero Muñoz suggests that while it is possible that the innkeeper thinks that Maese Pedro is Italian, it is more likely that 'la venta es lugar donde el italiano más o menos genuino de los veteranos suena con frecuencia' (the inn is a place where one frequently hears the more-or-less genuine Italian of veterans). ${ }^{\text {I }}$ Given Ginés de Pasamonte's skill in disguising himself, it is telling that as a traveller he does not directly respond to italianismos, further suggesting that his fear of being detected as a criminal outweighs any possible benefit of rejoining Don Quixote’s unusual ‘qué peje pillamo?’ (II. 25, 9I8) as Maese Pedro attempts to blend in. The puppeteer-rogue's aversion to using Italian is even more noticeable when one considers many cervantistas' explanation of the character's connection to Italy. These critics have reasonably suggested that the puppet-theatre portion of the episode in question is inspired by Cervantes's experiences with Sicilian puppi, and still others have invoked another Italian figure, that of the 'charlatan'. Despite the italianismos that surround him, Ginés de Pasamonte tellingly does not take the title 'Maestro', like 'Maestro Paolo da Arezzo', cited by Tomasso Garzoni in the sixteenth century as leading a troupe of mountebanks, including a certain 'Zan della Vigna with his performing monkey', who perfectly anticipates Maese Pedro's nonpuppet-show act. ${ }^{2}$ The criminal-turned-mountebank is surrounded by inadvertent intimations of criminal behaviour through the use of italianismos. Instead of looking towards Italy as a source of these phrases, can they not be derived from Cervantes's 
incarceration in the 'cultural meeting place' that was the Cárcel Real de Sevilla? Critics have stretched farther than this in making claims about the origin of Italianinspired loan-words in relation to criminality: "En cuanto al mote de "Ginesillo de Parapilla”, según recuerda Augustín Redondo, el apelativo Ginés se aplicaba a los villanos y el pillar es un italianismo que significa robar [...] (Recordemos que [Gerónimo de Pasamonte] vivió en Italia.)' (Regarding the moniker 'Ginesillo de Parapilla', as Augustín Redondo reminds us, the soubriquet Ginés was applied to country folk and 'pillar' is Italian in origin, meaning 'to steal' [...] (Let us recall that [Gerónimo de Pasamonte] lived in Italy))..$^{53}$ If we leave aside the question of whether the fictional Ginés de Pasamonte was created in a convoluted attempt to ridicule the real-life Gerónimo de Pasamonte, what remains is the association of 'robar' with 'pillar' by way of criminal behaviour. Such an association could have been observed by Cervantes while imprisoned in Seville, at least with the same likelihood that he learned of it while a free man in Italy. When looking further into the word 'pillar' from a different perspective, the question of genre overlaps with that of biography. In Juan Hidalgo's I609 Romances de germanía, the word 'pillar' and variations thereof appear eleven times, while in both parts of Don Quixote, it appears only once in obvious fashion, in the significant example of ‘Qué peje pillamo?’ cited above. If we interpret the use of italianismos as a reflection of incarceration in Seville, then the use of such expressions can be read as evidence of the overlap between the 'cultural meeting place' of the Cárcel Real de Sevilla and a Spanish venta that is a much more cheerful, if only slightly less comfortable, 'meeting place for travellers in the journey of life'. 54

Romero Muñoz's observation that 'la venta es lugar donde el italiano más o menos genuino de los veteranos suena con frecuencia, ${ }^{55}$ reminds us of Cervantes's travels in Italy, and also of the peripatetic soldier's life in general. Cervantistas rightly look to works such as El licenciado Vidriera to find further insight into this life and connections between that novel's characters, settings and situations and those in Don Quixote. In the case of El licenciado Vidriera, the search for insight in a literary vein can lead one to the genres of travel literature, folktales and the picaresque. ${ }^{56}$ Independent of the work in question, the picaresque is a genre that seems to have captured most critics' imagination when studying how an author encapsulates the soldier's life in prose. Even the sub-genre of soldiers' autobiographies are described in terms of the picaresque. For example, the autobiography of Gerónimo de Pasamonte has been described as 'a lively picaresque narration of his troubles as a child, journey to Italy, participation in the battle of Lepanto (I57I) and the battle of Tunis (I573)'.${ }^{57}$ It has been observed of another soldier's autobiography, Catalina de Erauso's Vida y sucesos de la monja alférez, that 'while [...] not a picaresque novel, some scholars have found sequences ['cross-dressing and boundary-crossing adventures'] that recall picaresque adventures. ${ }^{8}$ When studying any soldier's autobiography, we should be wary of ascribing too many picaresque elements, especially where criminal behaviour is concerned. Gerónimo de Pasamonte's Vida may feature 'a lively picaresque narration of his troubles as a child', but this is not some sort of generic pattern followed in other works. In Vida, nacimiento, padres y crianza del 
capitán Alonso de Contreras, the real-life hero of the story has a childhood featuring violent criminal behaviour that pushes the narrative outside of the realm of the picaresque. At one point in Contreras's narration he recounts how he exacted vengeance for a classmate's treachery by bringing him to the ground, stabbing him in the back, and then turning around the traitor to subsequently stab him in the stomach for good measure. 59 A modern historian cites the same 'Alonso de Contreras, [and his] picaresque account of his cruises with the knights [of Malta]' after introducing him as 'the Knight of Malta who bragged of torturing the Greeks he encountered', revealing that the 'picaresque' label can be somewhat misleading. ${ }^{60}$ Another genre category can be helpful in order to move in another direction and escape the dominance of picaresque fiction in the analysis of criminality in Spanish Golden Age literature. On the many occasions when the term pícaro does not apply to wandering soldiers and their violent adventures, we may instead refer to a valiente: the character type that has more in common with a jaque like the 'valiente Escarramán' from Cervantes's jácara, and less to do with the stereotypical cheeky and non-threatening pícaro. After the publication of Don Quixote, the term valiente was commonly used to describe a brawling character who gains literary prominence through comedias defined by such a protagonist. Consequently comedias de valiente (or valentón) are full of action scenes, although many of these may be re-enacted in stirring romance-style poems, if not performed in spectacular swordfights on stage. A great many comedias de capa y espada (cloak and dagger plays) have their share of swordfights, but these are used to punctuate complicated love plots, adding moments of tension or confusion. In the separate generic category of the comedia de valiente, the action mostly exists for action's sake. While fighting on stage adds excitement in its own right, the main purpose is simply to demonstrate the valiente's unerring valentía which is indistinguishable from a pure love of brawling. The early twentieth-century critic Emilio Cotarelo y Mori is still an excellent guide for studying lesser-known genres, and his list of valiente plays includes the following:

El valiente sevillano, de Enciso, El valiente Diego de Camas, de Enríquez Gómez; El valiente toledano, de Luis Vélez; El afanador el de Utrera, de Belmonte; Añasco el de Talavera, de Cubillo; El más valiente andaluz, Antón Bravo, de Monroy; Pero Vázquez de Escamilla, de Quevedo; El valiente Barrionuevo, de Cantón Salazar; El valiente Campuzano, de Zárate, hasta llegar a la famosa del Guapo Francisco Estevan, al Valiente Pedro Ponce, al Valor nunca vencido, hazañas de Juan de Arévalo y otras aún más disparatadas del siglo xvini. ${ }^{6 \text { I }}$

(El valiente sevillano, by Enciso, El valiente Diego de Camas, by Enríquez Gómez; El valiente toledano, by Luis Vélez; El afanador el de Utrera, by Belmonte; Añasco el de Talavera, by Cubillo; El más valiente andaluz, Antón Bravo, by Monroy; Pero Vázquez de Escamilla, by Quevedo; El valiente Barrionuevo, by Cantón Salazar; El valiente Campuzano, by Zárate, until we arrive at the famous Guapo Francisco Estevan, or Valiente Pedro Ponce, or Valor nunca vencido, hazañas de Juan de Arévalo and others from the eighteenth century that are even more ridiculous.)

Despite the prevalence of the word valiente in comedia titles, no generic distinction is perfect, and one must be sensitive to shades of meaning in Cervantes's use of the word, given the author's playful attitude towards genre conventions of all sorts. 
However he uses the word, it seems reasonable that there is always the potential that it refers to 'brawler' and not simply 'brave'. The expression valiente caballero is an operating cliché that serves Cervantes's chivalric parody well, but one cannot neglect his pervasive irony and love of double meaning for describing contradictory situations. Although Don Quixote claims chivalric knights as his model, the hero repeatedly and senselessly breaks the law in order to fulfil his fantasies. When he is accused of a crime or misconduct, Don Quixote answers in a manner foreshadowing his fellow valientes who will later populate the seventeenth-century stage. Despite the trail of bodies that those brawling and bullying characters leave behind them, the comedia protagonists must point out that, while they may be lawbreakers, they are honourable men, and certainly not thieves. Likewise, nobody can accuse Don Quixote of stealing or acting dishonourably, but by his own admission he remains a lawbreaker. More than that, he is a self-professed threat to law enforcement: '¿qué caballero andante ha habido, hay ni habrá en el mundo que no tenga bríos para dar él solo cuatrocientos palos a cuatrocientos cuadrilleros que se le pongan delante?' (I. 45, 580) ("what knight errant ever was, is, or will be in the world who does not have the courage to single-handedly deliver four hundred blows to four hundred Brotherhoods if they presume to oppose him?'). ${ }^{62}$ Compare this statement with that of the title character of El valiente Juan de Heredia:

Volvíme a Guadalcanal, de donde fue salir fuerza dentro de muy breve tiempo, huyendo de las molestias que la justicia me hacía por desgarros y pendencias, muertes y heridas, efetos de mi condición traviesa, si bien alabarme puedo que jamás, sin que tuviera ocasión, saqué la espada, que hay hombres que sin tenerla en sacarla cada instante para hacer mal se deleitan, bárbaramente imprudentes. ${ }^{63}$

(I came back to Guadalcanal, From where I was forced to leave, After very little time, Fleeing from the annoyances, That the police caused me, Because of the brawls and scraps, Murders and assaults, the results Of my mischievous nature, Though I can boast Of never drawing my sword Without good reason. There are men who always draw theirs Without justification, 
And enjoy doing harm,

Like senseless beasts.)

The valiente insists that he never drew his sword without cause, but the phrase 'las molestias que la justicia me hacía' reveals that (as with Don Quixote) when his cause is just, he may attack at will and ignore the repercussions of the law. Don Quixote's justification is that 'son esentos de todo judicial fuero los caballeros andantes, y que su ley es su espada, sus fueros, sus bríos, sus premáticas, su voluntad' (I. 45, 579) ('knights errant are exempt from all jurisdictional authority, [...] their law is their sword, their edicts their courage, their statutes their will'), ${ }^{64}$ but this does little to distinguish him from later valientes de comedia. Because Don Quixote is obsessed with books of chivalry, he easily conflates very real cuadrilleros with the typical hordes hewn down by fictitious superhero knights. This genre-based conflation does not distance him much from any saner, but equally violent, valiente literary type. However, there is one important distinction. In El valiente Juan de Heredia, the father figure and peacemaker the Conde de Palma intercedes on the hero's behalf in payment for Juan de Heredia's assistance in fighting off thieves. This intercession erases any potential for the valiente's criminal past to prevent his marriage to the Count's daughter. In Don Quixote, despite the protagonist's insistence that he is fighting for a noble cause while being pursued by the authorities, there is no powerful arbiter that can save him. He presents all the behaviour of a valiente de comedia without the means of escaping prosecution that the theatrical genre provides. The generic clash is also a clear reminder of what happens when the violent wishfulfilment fantasies of Don Quixote's favourite books are brought into the plane of reality. If we reflect upon the different appealing aspects of the books of chivalry, as outlined by the innkeeper, his wife, his daughter, and Maritornes in the first part of the novel, we will recall how the innkeeper exclaims, "cuando oyo decir aquellos furibundos y terribles golpes que los que los caballeros pegan, que me toma gana de hacer otro tanto' (I. 32, 405) ('when I hear about those furious, terrible blows struck by the knights, it makes me want to do the same'). ${ }^{65}$ His wife the ventera is glad that the stories are so engrossing that the men sit still and do not fulfil their violent fantasies. Citing tension between pacification and incitement only underlines the fact that Don Quixote has no break on his behaviour, is not content to simply sit and listen, and has instead become an uncontrollable brawler. Of course, as a multidimensional character, he is more than that. He is also a lover who takes his cues in romance from the same books, but if forced to decide between being a lover or a fighter, Don Quixote would squarely fall into the second camp. At the end of Chapter 45 , he swore in his rhetorical questions to be among those who will deal 'cuatrocientos palos a cuatrocientos cuadrilleros que se le pongan delante' (580). At the very beginning of Chapter 46 , titled 'De la notable aventura de los cuadrilleros y la gran ferocidad de nuestro buen caballero don Quijote' ('Regarding the notable adventure of the officers of the Holy Brotherhood, and the great ferocity of our good knight Don Quixote'), ${ }^{66}$ the law-enforcement officials effectively drop their charges against Don Quixote by reason of his insanity and the hero's status reverts from threatening valiente to bumbling madman. After the tension drops and the 
tone shifts, the narrator leaves us with a lingering ironical commentary. If we keep in mind the ambiguity of the word valiente, the sub-text rises to the surface as we read about the lovers and fighters who occupy the inn:

Sosegadas, pues, estas dos pendencias, que eran las más principales y de más tomo, restaba que los criados de don Luis se contentasen de volver los tres, y que el uno quedase para acompañarle donde don Fernando le quería llevar; y como ya la buena suerte y mejor fortuna había comenzado a romper lanzas y a facilitar dificultades en favor de los amantes de la venta y de los valientes della, quiso llevarlo al cabo y dar a todo felice suceso. (I. 46, 58I)

(Having settled these two disputes, which were the most important and most pressing, it remained only for Don Luis's servants to agree that three would return home while one stayed behind to accompany him wherever Don Fernando wished to take him; since good luck had begun to intervene in favor of the lovers and the valiant people at the inn, overcoming all difficulties, a better fortune wished to bring everything to a happy conclusion. $)^{67}$

The 'amantes' refer to the embedded love story of Doña Clara and Don Luis, and 'valientes' can only be ascribed to the narrowly-avoided confrontation between the novel's hero and la justicia, a scene that would have been reminiscent of many from the comedias de valiente.

Those familiar with the comedias de valiente can argue that most of these plays were written well after the first part of Don Quixote, and many may indeed wonder if the connections made above are tenuous. I believe that the comparisons are fair and fruitful, especially if one considers the extremely common use of the word 'picaresque' in studies on Don Quixote. Before publication of the first part of the novel, only two widely recognized picaresque works circulated in printed form, namely Guzmán de Alfarache and, half a century before, the work that started them all, La vida de Lazarillo de Tormes, $y$ de sus fortunas $y$ adversidades. The bulk of picaresque fiction, in the loosest use of the term, was published after the first part of Don Quixote, yet the designation is used as though Cervantes had read all of these works years or even decades before they were printed. If the term 'picaresque' is licit for analysing the representation of criminality in Cervantes, then so is the word valiente in reference to the theatrical genre based upon the character-type. Since we know that Cervantes had an eye fixed on Lope de Vega's works, and Lope did write El valiente Céspedes between I6I2 and $16 \mathrm{I}_{5},{ }^{68}$ we can be sure that the novelist was aware of the word's current usage before he died and most likely when he began to write Don Quixote. Also, Lope wrote another play about a figure associated with the underworld, El rufián Castrucho, likely in I598. ${ }^{69}$ Although that play's protagonist has been called a combination of fanfarrón (braggart) and pícaro, ${ }^{70}$ when Castrucho the protagonist declares, 'verás lo que se llama valentía | [...] arrímate a la esquina, que es en vano | estorbar la venganza y el cuchillo [...], ${ }^{7 \mathrm{I}}$ ('I'll show you who's tougher | [...] go head for the corner, it's useless | trying to stop vengeance and a knife') it is evident that Lope has fashioned this figure in the valiente mould and was aware of the reckless love for brawling often implied in the word valentía.

If we add together prison narratives, jácaras, comedias de valiente, all genres that specifically deal with lawbreakers and peacekeepers, we begin to see that the 
expression 'picaresque' is inadequate for a holistic study of cultural and literary influences on the portrayal of criminality in Don Quixote. In addition to an expanded generic approach, we have the option of returning to the historical moment, as recorded by those working within and around the early modern prison system of Seville. It is my hope that with the examples given above we might take a respite from using the picaresque as a point of reference and in this way explore more deeply and more widely crime and punishment in the novel.

\section{Notes to Chapter 8}

I. Howard Mancing, 'Guzmán de Alfarache and After: The Spanish Picaresque Novel in the Seventeenth Century', in The Picaresque Novel in Western Literature: From the Sixteenth Century to the Neopicaresque, ed. by J. A Garrido Ardila (Cambridge: Cambridge University Press, 20I5), pp 40-59 (p. 50).

2. Miguel de Cervantes Saavedra, Don Quixote, trans. by Edith Grossman (London: Secker \& Warburg, 2004), p. 3. All translations from Don Quixote are taken from this edition except where otherwise stated.

3. José Miguel Cabañas Agrela, Breve historia de Cervantes (Madrid: Nowtilus, 20i6), pp. 222-23.

4. All translations from texts other than Don Quixote are my own.

5. Mary Elizabeth Perry, Crime and Society in Early Modern Seville (Hanover, NH: University Press of New England, I980), p. 28.

6. Pedro Herrera Puga, Sociedad y delincuencia en el Siglo de Oro: aspectos de la vidasevillana en los siglos XVI Y XVII (Granada: Universidad de Granada, Secretariado de Publicaciones, I97I), p. II7.

7. Ellen M. Anderson and Gonzalo Pontón Gijón, 'La composición del Quijote', in DQ, pp. cxcii-ccxx (p. cxcii).

8. Anderson and Pontón, p. cxciii.

9. Mary Elizabeth Perry, Crime and Society in Early Modern Seville, pp. 77, 79.

Io. Gerald L. Gingras, 'Relación de cómo Ginés de Pasamonte se desprendió de su cárcel literaria', in Cervantes y su mundo, ed. by Kurt Reichenberger and Darío Fernández-Morera, 3 vols (Kassel: Reichenberger, 2004), II, I93-226.

II. As quoted in Gingras, p. 215 , n.I.

I2. Juergen Hahn, 'Rinconete y Cortadillo in Don Quijote: A Cervantine Reconstruction', Modern Language Notes, II6.2 (200I), 2II-34 (p. 219).

I3. E. Michael Gerli, Refiguring Authority: Reading, Writing, and Rewriting in Cervantes, Studies in Romance Languages, 39 (Lexington Kentucky: The University Press of Kentucky, I996), p. 20.

I4. p. I68.

I5. p. I65.

I6. Miguel de Cervantes, El ingenioso hidalgo Don Quijote de la Mancha, ed. by Diego Clemencín, 6 vols (Madrid: Aguado, I833-39; repr. Madrid: Castilia, I967), II, single footnote on p. I98.

I7. Adapted from Grossman's translation, p. I67.

I8. Cervantes, El ingenioso hidalgo, ed. Clemencín, II, single footnote on p. 204; translation based on Grossman, p. I67.

I9. Cervantes, El ingenioso hidalgo, ed. Clemencín, II, single footnote on p. 205.

20. Jesús G. Maestro, Crítica de los géneros literarios en el 'Quijote': idea y concepto de género en la investigación literaria (Vigo: Academia del Hispanismo, 2009), p. 248.

2I. Maestro, p. 248.

22. As cited in Pedro Herrera Puga and Pedro de León, Grandeza y miseria en Andalucía: testimonio de una encrucijada histórica, I578-I6I6 (Granada: Facultad de Teología, I98I), p. 22I.

23. Joaquín Casalduero, Sentido y forma del 'Quijote', (1605-1615), 3rd edn (Madrid: Ínsula, I970), p. II9.

24. My translation of the phrases in commas is based on Grossman, p. I67. 
25. Anthony Close, 'The Liberation of the Galley Slaves and the ethos of Don Quijote Part I', Cervantes: Bulletin of the Cervantes Society of America, 27.I (Spring 2007 [2008]), 7-30 (p. I5).

26. Close, 'The Liberation', p. i6; translation from same page.

27. Close, 'The Liberation', p. I7.

28. Anthony Close, A Companion to 'Don Quixote', Colección Támesis Serie A: Monografías (Woodbridge: Tamesis, 20I0), p. 262.

29. César Hernández Alonso and Beatriz Sanz Alonso, Germanía y sociedad en los siglos de oro: la cárcel de Sevilla (Valladolid: Secretariado de Publicaciones e Intercambio Editorial, Universidad de Valladolid, I999), p. I75.

30. José M. Blecua, Sobre poesía de la Edad de Oro: ensayos y notas eruditas (Madrid: Gredos, I970), p. 189 .

3I. See Luis Astrana Marín, La vida turbulenta de Quevedo (Madrid: Gran Capitán, I945), p. I8I; Elena Di Pinto, La tradición escarramanesca en el teatro del Siglo de Oro (Madrid: Iberoamericana, 2005), p. 29; Vicente Pérez de León, Tablas destempladas: los entremeses de Cervantes a examen (Alcalá de Henares, Madrid: Centro de Estudios Cervantinos, 2005), p. I69.

32. As cited in Emma Nishida, 'Los romances y el lenguaje de germanía en el entremés del Rufián viudo: ¿mensajes pícaros de Cervantes hacia Alonso Fernández de Avellaneda?', in Tus obras los rincones de la tierra descubren. Actas del VI Congreso Internacional de la Asociación de Cervantistas. Alcalá de Henares, 13 al 16 de diciembre de 2006, ed. by A. Dotras Bravo and others (Alcalá de Henares: Centro de estudios cervantinos, 2008), pp. 59I-600 (p. 596).

33. p. I34.

34. As cited in John M. M. Hill, Poesías germanescas (Bloomington: Indiana University Press, I945), pp. $65,66$.

35. As cited in Hill, Poesías, p. 70.

36. As cited in Hill, Poesías, p. 84.

37. Gerli, Refiguring Authority, p. 20.

38. As cited in Hill, Poesías, p. 89.

39. p. 165 .

40. Ryan Prendergast, Reading, Writing, and Errant Subjects in Inquisitorial Spain (Farnham: Ashgate, 20II), p. 84 .

4I. See, for example, Chad M. Gasta, 'Cervantes and the Picaresque: A Question of Compatibility', in The Picaresque Novel in Western Literature: From the Sixteenth Century to the Neopicaresque, ed. by J. A Garrido Ardila (Cambridge: Cambridge University Press, 20I5), pp. 96-II2 (p. 99).

42. Nishida, 'Los romances y el lenguaje de germanía', p. 596.

43. Felipe B. Pedraza Jiménez, 'De Quevedo a Cervantes: la génesis de la jácara', in Edad de Oro Cantabrigense: Actas del VII Congreso de la Asociación Internacional Siglo De Oro (AISO): (Robinson College, Cambridge, 18-22 Julio, 2005) (Madrid: Iberoamericana, 2006), pp. 77-88 (p. 8I).

44. Perry, Crime and Society, p. 83.

45. p. 620.

46. pp. 62I, 62I again, 622, respectively.

47. p. 624, emended. Grossman's translation puts 'uomo galante' for the Spanish 'hombre galante' and 'bon compagno' for 'bon compaño'.

48. p. 6I8 fn. 3, "The word means "miserliness" or "stinginess"; p. 624, fn. I, 'literally, "what fish are we catching?" or "what are we up to, what are we doing?",

49. Carlos Romero Muñoz, 'Nueva lectura de El retablo de Maese Pedro', in Actas del I Coloquio Internacional de la Asociación de Cervantistas (Madrid: Anthropos, I990), pp. 95-I30 (pp. I08-09).

50. My translation; Grossman's translation leaves untranslated (p. 8I2).

5I. Romero Muñoz, p. Io9.

52. Winifred Smith, The Commedia dell'Arte: A Study in Italian Popular Comedy (New York: Columbia University Press, I9I2), p. 34 .

53. Helena Percas de Ponseti, 'Un misterio dilucidado: Pasamonte fue Avellaneda', Cervantes: Bulletin of the Cervantes Society of America, 22.I (2002), I27-54 (pp. I3I-32).

54. Frederick A. de Armas, 'The Artful Gamblers: Wagering Danaë in Cervantes' Don Quixote I. 33-35', in Objects of Culture in the Literature of Imperial Spain, ed. by Mary E. Barnard and Frederick A. de Armas (Toronto: University of Toronto Press, 2013), pp. 54-79 (p. 55). 
55. Romero Muñoz, p. Io9.

56. Stephen Rupp, 'Soldiers and Satire in El Licenciado Vidriera', in A Companion to Cervantes's 'Novelas Ejemplares', ed. by Stephen Boyd (Woodbridge: Tamesis, 2005), pp. I34-47 (pp. I34$35)$.

57. Germán Bleiberg, Maureen Ihrie, and Janet Pérez, Dictionary of the Literature of the Iberian Peninsula, 2 vols (Westport, CT: Greenwood, I993), II, I234.

58. Sonia Pérez-Villanueva, The Life of Catalina de Erauso, the Lieutenant Nun: An Early-Modern Autobiography (Madison: Fairleigh Dickinson University Press, 20I4), p. IOI.

59. Alonso de Contreras, Vida, nacimiento, padres y crianza del capitán Alonso de Contreras, ed. by Fernando Reigosa (Madrid: Alianza Editorial, I967), p. 52.

6o. Molly Greene, Catholic Pirates and Greek Merchants: A Maritime History of the Mediterranean (Princeton: Princeton University Press, 2010), pp. I2I, II.

6I. Obras de Lope de Vega, ed. by Emilio Cotarelo y Mori, I3 vols. (Madrid: Revista de Archivos, Bibliotecas y Museos, I9I6-I930), II, p. Xv. 62. p. 397.

63. [Attributed in] Obras de Lope de Vega, II, p. 649.

64. p. 397.

65. p. 267.

66. p. 398.

67. pp. 398-99.

68. Edwin S. Morby, 'Some Observations on tragedia and tragicomedia in Lope', Hispanic Review, i I.3 (I943), I85-209 (p. I89).

69. Lope de Vega, El rufián Castrucho (Madrid: RESAD, 200o), p. 20

70. Juan Oleza, 'La propuesta teatral del primer Lope de Vega', in Teatro y prácticas escénicas: II, ed. by Ana Giordano Gromegna (London: Tamesis, I986), pp. 25I-308 (p. 305).

7I. Lope de Vega, El rufián Castrucho, p. I50. 